\title{
Soil Pollution: A Case Study on the Determination of Toxic Elements in Soil in Jeddah City, Saudi Arabia
}

\author{
Basma G. Alhogbi ${ }^{1}$, Amani. F. Alsolame ${ }^{1}$ \\ ${ }^{1}$ King Abdulaziz University, Faculty of Science, Department of Chemistry, Jeddah, Saudi Arabia. \\ Correspondence: Basma G. Alhogbi, King Abdulaziz University, Faculty of Science, Department of Chemistry, Jeddah, \\ Saudi Arabia. E-mail: balhogbi@kau.edu.sa, alhogbib@gmail.com.
}

\author{
Received: February 3, 2017 Accepted: March 8, 2017 Online Published: March 14, 2017 \\ doi:10.5539/ijc.v9n2p37 \\ URL: https://doi.org/10.5539/ijc.v9n2p37
}

\begin{abstract}
A considerable increase in the population of Jeddah City and the construction of new residential areas in the last few years has been noticed. Thus, a total of 23 soil samples were collected from three different areas of Sewage Lake, namely, Area A (polluted; the highest concentration of toxic elements), Area B (Southeast), and Area C (Northwest) for the analysis of toxic elements. The soil samples were digested by acid digestion to quantify the $\mathrm{As}, \mathrm{Co}, \mathrm{Cr}, \mathrm{Hg}, \mathrm{Ni}, \mathrm{V}, \mathrm{Pb}$, and $\mathrm{Zn}$ using Inductively Coupled Plasma- Optical Emission Spectrometry (ICP-OES). Zn has the highest concentration in all studied areas $(4821 \pm 10.2 \mathrm{mg} / \mathrm{kg}$ for $\mathrm{A}, 1108.6 \pm 9.5 \mathrm{mg} / \mathrm{kg}$ for B and $2339.8 \pm 8.7 \mathrm{mg} / \mathrm{kg}$ for C). On the other hand, $\mathrm{Cr}$ concentration was found $872 \pm 2.5 \mathrm{mg} / \mathrm{kg}$ for A, $1128 \pm 5.4 \mathrm{mg} / \mathrm{kg}$ for B and $680 \pm 3.4 \mathrm{mg} / \mathrm{kg}$ for C. These elements were above the level of the quality guidelines ( $300 \mathrm{mg} / \mathrm{kg}$ for $\mathrm{Zn}$ and $4.0 \mathrm{mg} / \mathrm{kg}$ for $\mathrm{Cr}$ ). In majority of the area $\mathrm{C}$ samples, the concentration of $\mathrm{Hg}$ was found below the detection limit. The results indicated that the area $\mathrm{A}$ has a significantly higher metal contents as it is an inference polluted area. Hence, it is influencing the level of metal concentrations in area B, and area $\mathrm{C}$ might be due to wind spread. The indiscriminate disposal of hazardous waste in the study area causes a significant source of the soil contamination.
\end{abstract}

Keywords: Heavy metal, Jeddah, Saudi Arabia, Sewage Lake, Soil assessment

\section{Introduction}

There has been an immense amount of global concern over the last three decades about attributing polluted environmental influences to the public health (UNEP 2011). The World Health Organization estimates that about a quarter of the diseases facing humaneness nowadays occur due to the long exposures of environmental pollution. In many cities, the inappropriate management of solid waste was the main reason of environmental pollution even in the developed countries (Sow et al., 2013). In urban areas, toxic elements can be easily transmitted into the human body because of inhalation, dermal contact absorption, and ingestion. Then, because of their non-biodegradable nature and long biological half-lives for eliminating the heavy metals accumulated in the human body ( $\mathrm{Li} \mathrm{Z}$ et al., 2014; Zhao et al., 2012).

Solid wastes have been classified as garbage, rubbish, household refuse, and litter. It is well known that the sea dumping (creates water pollution and destroys marine habitats), incineration (leads to atmospheric pollution, if not conducted under controlled conditions), The landfill (the most widely used method till its limitations are realized in recent years), and recycling were the four main ways of disposing of solid wastes (Lim et al., 2008). Moreover, the elements travel for considerable distances were also deposited onto the soil, vegetation, and water depending on their density (Alloway and Ayres, 1997). Solid pollutants can be a source of air and water pollution. In addition, open dumps were a cause of land pollution. Therefore, Solid wastes discharged into the water can be hazardous to aquatic life directly or indirectly (Kelepertzis, 2014).

Jeddah is the most important commercial city in the Kingdom of Saudi Arabia. The UNESCO recognizes the historical town of Jeddah as World Heritage site (CIA, 2012; Habibullah, 2014). It has not been dated precisely that Jeddah as a coastal settlement was a transit point for Eastern trade in the past. However, the environmental pollution has always been one of the last concerns when it comes to the city activates and development. Since1962, Jeddah has been expanding rapidly at an astonishing rate. The biggest source of pollution was the sewage lake in Jeddah (Jeddah east) because it contained toxic elements due to the deposition of water in the residential area (Magram, 2009). Toxic elements, such as $\mathrm{As}, \mathrm{Ba}, \mathrm{Be}, \mathrm{Cr}, \mathrm{Cd}, \mathrm{Pb}, \mathrm{Hg}, \mathrm{Ni}$, and $\mathrm{Zn}$, are the presence of the waste of incineration and coal combustion, which may be detrimental to human health from their exposure to emissions (Lawrence, et al., 2005). The 
industrialization of modern societies resulted in a vast increase of refuse generated per person. In 2016 Saudi Arabia, solid waste reached 15 million tons per year, commonly known as trash or garbage more than 6 million tons per year the solid waste rate of the three biggest cities- Riyadh, Jeddah, Dammam (EcoMENA, 2016).

Natural concentrations of toxic elements in soil derive either from the weathering of parent bedrock or come from some external source. Organic metal species are often more bioavailable and hence potentially more hazardous to higher organisms (Ron, et al., 1992). The experimental conditions, $\mathrm{pH}$, redox potential, clay mineral, organic matter and water contents, have significant impacts on the mobility of heavy metals in soil. Different methods (adsorption-desorption, complex and ion-pair formation or activities of microorganisms (Gabler, 1997)) have been used in the removal of heavy metals from the soils. The most mobile is the element and complex cations, medium mobility is the exchangeable cations in organic and inorganic complexes and, slightly mobile are the chelated cations.

In Jeddah city, the Sewage Lake represents a danger to the environment surrounding it. Although it is dried in (2011) by Jeddah Municipality, toxic elements accumulated in the sediment can be translocated to the residential areas around by the blowing wind. However, there has been no systematic gathering and inter-comparison of toxic element concentrations, their levels of contamination and pollution sources. Therefore, the present article reports the levels of selected toxic metal content and subsequent soil pollution levels in Jeddah urban soils. The sample collection, sources, contamination levels, and analytical tools used are presented in this study.

\section{Methods and Materials}

\subsection{Study Area}

Jeddah has expanded in the last three decades, and the expansion continues at an unpredictable rate. New districts have continued to grow and accommodate the increasing population. Growth is also occurring in the countryside of Jeddah. One of the largest sources of pollution in the city of Jeddah is the presence of Sewage Lake (established since 1992), which extends over an expanse of $2.6 \mathrm{~km}^{2}$. It became the central sewage downstream, with the passage of time, the stretch of residential areas, the lake poses a danger to the neighborhoods adjacent to the lake, as it became filled with toxic elements, which affecting the soil, air, and water. The movement of these elements became easier with rising water to approximately 19 million $\mathrm{m}^{3}$. One of these new residential areas is located nearby the Sewage Lake. It is a one of the largest sources of pollution, located east of the city, east of the highway along the way Hada al-Sham extended to the Makah. Over $17 \mathrm{~km}$ away from the study area (districts: Al Samer 1, 2, 3, 4, and 5, and Al -Ajwad in the northwest of the lake and the National Park area in the southeast of the lake. The lake presents a substantial risk to the area surroundings and the population (Jeddah Municipality, 2010).

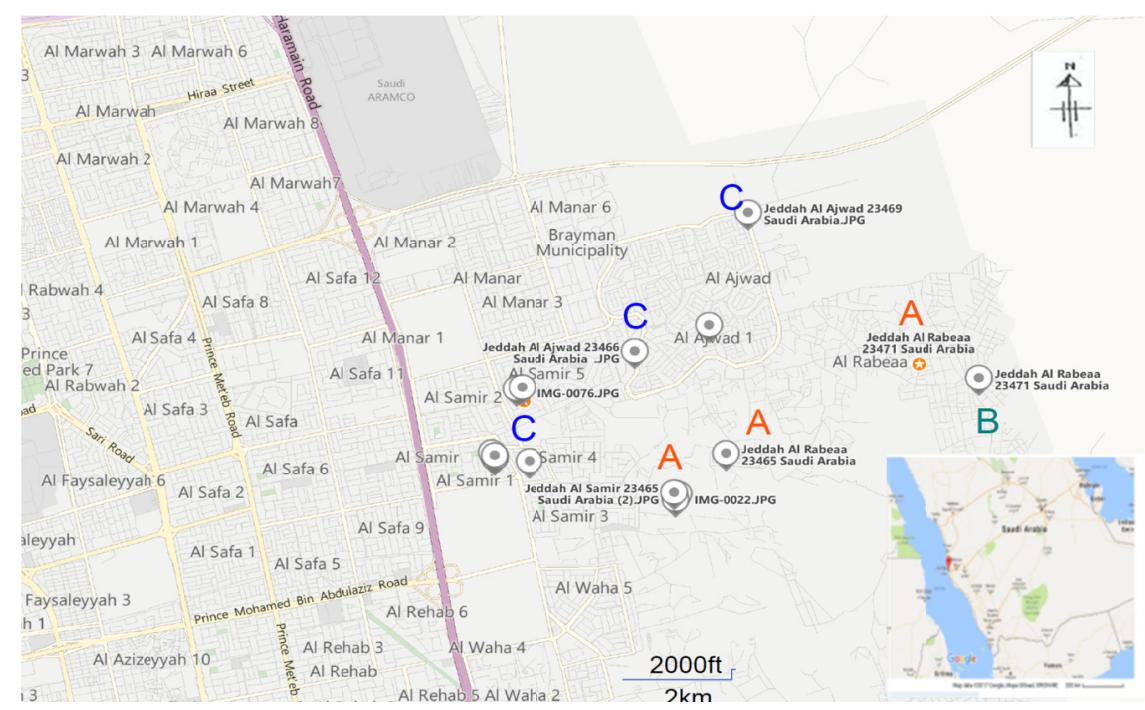

Figure 1. Location of soil samples at the Polluted area (A), Southeast polluted area (B), and Northwest polluted area (C). 
Table 1. Locations and numbers of samples of the studied areas, Jeddah, Saudi Arabia

\begin{tabular}{|c|c|c|}
\hline Sample & Areas & Locations \\
\hline 1 & \multirow{7}{*}{ A } & Dam lake, Jeddah Al Rabeaa 23471 Saudi Arabia \\
\hline 2 & & Lake (color of the soil is light brown) \\
\hline 3 & & Lake (color of the soil is dark brown) \\
\hline 4 & & Lake's flood, Al Samir 23465 Jeddah \\
\hline 5 & & Dam, Jeddah Al Samir 23465 \\
\hline 6 & & Dam near the lake, Jeddah Al Samir 23465 \\
\hline 7 & & Border of National Park, 21.580239, 39.263786 \\
\hline 8 & \multirow[t]{3}{*}{ B } & Center of the National Park \\
\hline 9 & & National park under the trees \\
\hline 10 & & $\begin{array}{l}2868 \text { Mohammed Bin Abdulla Al Amawi Street Jeddah Al Samir } \\
\text { 23461-7384 }\end{array}$ \\
\hline 11 & \multirow{13}{*}{$\mathrm{C}$} & 3959 Abi Abdulrahman Al-Qaseer Street Jeddah Al Samir 23462-6579 \\
\hline 12 & & 3321 Ismail Al Mekali Street Jeddah Al Samir 23464-7245 \\
\hline 13 & & $\begin{array}{l}\text { Park, } 2924 \text { Ali Bin Mohammad Al Bayyari Street Jeddah Al Samir } \\
\text { 23461-7329 }\end{array}$ \\
\hline 14 & & Center of the park, 2924 Street Al Aasha Al Mazni \\
\hline 15 & & Border of the park, 2924 Street Al Aasha Al Mazni \\
\hline 16 & & Football playground in the park - AL Samer 5 \\
\hline 17 & & Children playground AL Samer 5- Street Omar Bin Hussein \\
\hline 18 & & $\begin{array}{l}\text { Football children playground, } 6538 \text { Omar Bin Husain Street Jeddah Al } \\
\text { Samir 23462-3888 }\end{array}$ \\
\hline 19 & & Border of the park, 6538 Street Omar Bin Hussein \\
\hline 20 & & Circular, Jeddah Al Ajwad 23469 \\
\hline 21 & & Circular street in AL Ajawad -street Solayman Bin Morad \\
\hline 22 & & $\begin{array}{l}\text { Border of the park, AL Ajawad } 3887 \text { Sulaiman Murad Street Jeddah Al } \\
\text { Ajwad 23466-6713 }\end{array}$ \\
\hline 23 & & Center of the park, Jeddah Al Ajwad 23466 \\
\hline
\end{tabular}

\subsection{Sampling and Soil Sample Preparation}

The overall number of soil samples is 23 , which were collected from the three distinct areas by using top surface soil having 5-10 cm depth. These three distinct areas (A, B, C): 1- Area (A) (6 samples) represents the lake drainage and the area around it which have, contaminated water of the lake, due to the flood to the valley and the low-lying area. 2National Park, area (B), (3 samples) located southeast of the lake and are irrigated by the water recycled from the lake. 3- Residential neighborhoods adjacent to the lake, area (C) (14 samples) in the northwest and whose levels are below the lake level. Samples are collected from public parks the soccer field for children (16 to 19) and open land. The sampling points and their locations are shown in Fig. 1, and listed in Table 1. Soil samples were dried by spreading out on a clean plastic sheet over a bench in the laboratory, stones and plant roots were removed manually. Samples were left to dry at room temperature for a week. Air-dried samples were sieved through a $1.4 \mathrm{~mm}$ stainless steel sieve, and the samples were stored at room temperature in self-sealing plastic bags. The $\mathrm{pH}$ of the samples was measured by using a digital $\mathrm{pH}$ meter (Mettler Toledo MP220), and the range was found to be a $7.45-9.3$. The average conductivity of the soil was $3000 \mu \mathrm{s}$.

\subsection{Concentration of Samples in the Soil}

The acid digestion technique was used for the determination of environmentally toxic elements (Ure, 1995) even at low concentration. Aqua regia was prepared by mixing three parts $6 \mathrm{M} \mathrm{HCl}$ to one part $\mathrm{HNO}_{3} 6 \mathrm{M}$. Soil samples $(0.5 \mathrm{~g})$ were weighed using a four-figure balance in three replicates. Each sample was poured into a $50 \mathrm{ml}$ beaker containing $10 \mathrm{ml}$ 
of aqua regia solution. The solution was allowed to stand for at least $12 \mathrm{~h}$ to allow the acid to equilibrate with the soil, which was placed on the hot plate preheated at $125^{\circ} \mathrm{C}$. The digestion was run for $3 \mathrm{~h}$ until the evaluation of brown gas. The beakers were cooled and a $10 \mathrm{ml}$ of deionized water was added for dilution. The digests were filtered using a hardened filter paper Whatman No. 50, and washed with deionized water. The filtrate and washing were collected in 50 $\mathrm{ml}$ volumetric flasks and made up to volume. Average values of three replicas were taken for each determination for precision and accuracy. Samples were measured by ICP-OES (7000 DV Perkin Elmer).

\section{Results and Discussion}

\subsection{Acid Digestion}

The toxic metals concentrations are summarized in Table 2, and representative data are depicted in Fig. 3. It was detected that the study areas have the highest $\mathrm{Zn}$ content $(4821 \pm 10.2 \mathrm{mg} / \mathrm{kg}$ for A, $1108.6 \pm 9.5 \mathrm{mg} / \mathrm{kg}$ for B and $2339.8 \pm 8.7 \mathrm{mg} / \mathrm{kg}$ for C) and obvious is much higher than the tolerable level $300 \mathrm{mg} / \mathrm{kg}$ for $\mathrm{Zn}$. The $\mathrm{Zn}$ concentration in the area (A) is low in the drainage lake. The fact that the lake is a waterborne sewage from homes, which has a high zinc content due to the containment of water by the zinc composition of the detergents and soap. In all areas $\mathrm{Cr}$ concentration was found very high $872 \pm 2.5 \mathrm{mg} / \mathrm{kg}$ for A, $1128 \pm 5.4 \mathrm{mg} / \mathrm{kg}$ for B and $680 \pm 3.4 \mathrm{mg} / \mathrm{kg}$ for C, comparing with the permissible limit $4.0 \mathrm{mg} / \mathrm{kg}$. Many of the metals have a strong affinity to a natural organic material because of its many functional groups. Therefore, it is adsorbed and accumulated in the upper soil layers, which has most abundant organic materials. Metal ions may also have adsorbed on the surface of the clay mineral and $\mathrm{Mn}, \mathrm{Fe}$ and $\mathrm{Al}$ oxides/hydroxides. In general, $\mathrm{Pb}$ and $\mathrm{Cu}$ are adsorbed most strongly, while $\mathrm{Zn}$ and $\mathrm{Cd}$ are adsorbed more weakly to the soil. Consequently, the metals which are adsorbed less strongly are more bioavailable (Ron, et al., 1992). Zn and V followed the descending order: area (A) $>$ area $(C)>$ area (B). The average grades and tolerable level of toxic metals using aqua regia digestion in area $\mathrm{A}, \mathrm{B}$, and $\mathrm{C}$ are listed in Table.3. Moderately high concentration of $\mathrm{Pb}$ was noticed in the area (A) $(700.5 \pm 149 \mathrm{mg} / \mathrm{kg})$, in the northwest to the polluted area (C) is $(674.6 \pm 184 \mathrm{mg} / \mathrm{kg})$ and in area (B) the southeast is $(792.33 \pm 167 \mathrm{mg} / \mathrm{kg})$ this high concentration of $\mathrm{Pb}$ in area $\mathrm{B}$ may be due to the irrigation of the soil by recycling water from the sewage lake. As, $\mathrm{Co}$, and $\mathrm{Hg}$ followed the descending order: area $(\mathrm{A})>$ area $(\mathrm{B})>$ area $(\mathrm{C})$. $\mathrm{Ni}$ and $\mathrm{Cr}$ exist in the orders area $(\mathrm{B})>$ area $(\mathrm{A})>$ area $(\mathrm{C})$, the high concentration in area $\mathrm{B}$ might be due to wind blowing.

The direction of the wind in the city of Jeddah from south to north leads to the movement of air from the contaminated area to the northwestern region, which includes the neighborhoods adjacent to the lake. Thus the concentration of toxic elements is less in the southeastern region, including the National Park which is located almost a back of the lake drainage and thus the direction of the wind does not help in the transmission of heavy elements to it. Also in this region is geographically higher than the area of Sewage Lake; hence water rains and floods spread from the highlands to the lower area, and thus led lake water flood to the northwestern region. Air winds carry the dust particles who contaminated by heavy metals. It remains in the air for varying the length of time depending on the size of the carrying particle, relative humidity, and wind speed and precipitation amount. The particles with a diameter $<10 \mu \mathrm{m}$ may remain in the atmosphere for 10-30 days and are removed primarily by washout and can be transported several thousand kilometers away from their sources, depending on the air mass movements (Sow, et al., 2013).

Adham, et al., 2011 have reported the toxic metal pollution in Riyadh city. The levels of $\mathrm{Ni}, \mathrm{Cu}, \mathrm{Pb}$ and $\mathrm{Hg}$ were found $14.37,53.64,5.223$ and $0.24 \mu \mathrm{g} \mathrm{g}^{-1}$, respectively. Thus, the metal concentrations in this study were higher than those from that the mean concentrations of $\mathrm{Cu}, \mathrm{Zn}$ and $\mathrm{Pb}$ in the soil of Shenyang, China reached to 51.26, 140.02 and 75.29 $\mathrm{mg} / \mathrm{kg}$, respectively. The Hong Kong $\left(0.36 \pm 0.16 \mathrm{mgkg}^{-1} \mathrm{Cd}, 16.2 \pm 5.92 \mathrm{mgkg}^{-1} \mathrm{Cu}\right.$, and $\left.103 \pm 91.3 \mathrm{mgkg}^{-1} \mathrm{Zn}\right)$ (Odewande, and Abimbola, 2008). The Thrace region $\left(0.2 \mathrm{mgkg}^{-1}, \mathrm{Cd} 20 \mathrm{mgkg}^{-1} \mathrm{Cu}, 33 \mathrm{mgkg}^{-1} \mathrm{~Pb}\right.$ and $45 \mathrm{mgkg}^{-1} \mathrm{Zn}$ ) (Lee, et al., 2006) the Zagreb region $\left(20.8 \mathrm{mg} \mathrm{kg}^{-1} \mathrm{Cu}, 25.9 \mathrm{mgkg}^{-1} \mathrm{~Pb}\right.$ and $77.9 \mathrm{mgkg}^{-1} \mathrm{Zn}$ ) (Cos, et al., 2006). The worldwide average and much lower than other cities, e.g. Ibadan $\left(8.4 \pm 19.78 \mathrm{mgkg}^{-1} \mathrm{Cd}, 95.1 \pm 126.68 \mathrm{mgkg}^{-1} \mathrm{~Pb}\right.$ and $228.6 \pm 366.28 \mathrm{mgkg}^{-1} \mathrm{Zn}$ ) (Romic, and Romic D., 2003) and Mortagne du Nord (1.92 $\pm 0.81 \mathrm{mgkg}^{-1} \mathrm{Cd}$ and $230.8 \pm 146.3$ $\mathrm{mgkg}^{-1} \mathrm{~Pb}$ ) (Douay, 2007). 
Table 2. Concentrations ( $\mathrm{mg} / \mathrm{kg}$ ) Average of three replicate of toxic metals in soil using aqua regia

\begin{tabular}{|c|c|c|c|c|c|c|c|c|c|}
\hline Sample & Areas & As & $\mathrm{Co}$ & $\mathrm{Cr}$ & $\mathrm{Ni}$ & $\mathrm{Pb}$ & $\mathrm{V}$ & $\mathrm{Zn}$ & $\mathrm{Hg}$ \\
\hline 1 & \multirow{7}{*}{ A } & $100.0 \pm 0.002$ & $262.0 \pm 0.012$ & $734.0 \pm 0.032$ & $362.0 \pm 0.009$ & $826.0 \pm 0.036$ & $310.0 \pm 0.026$ & $1690 \pm 0.09$ & $378.0 \pm 0.91$ \\
\hline 2 & & $114.0 \pm 0.013$ & $290.0 \pm 0.014$ & $884.0 \pm 0.046$ & $412.0 \pm 0.017$ & $957.0 \pm 0.010$ & $288.0 \pm 0.048$ & $3090 \pm 0.352$ & $264.0 \pm 0.132$ \\
\hline 3 & & $112.0 \pm 0.008$ & $298.0 \pm 0.018$ & $830.0 \pm 0.022$ & $392.0 \pm 0.010$ & $710.0 \pm 0.010$ & $142.0 \pm 0.018$ & $1878 \pm 0.010$ & $136.0 \pm 0.068$ \\
\hline 4 & & $132.0 \pm 0.006$ & $324.0 \pm 0.017$ & $1054 \pm 0.078$ & $552.0 \pm 0.021$ & $545.0 \pm 0.010$ & $\mathrm{BDL} *$ & $9428 \pm 0.155$ & BDL \\
\hline 5 & & $142.0 \pm 0.006$ & $340.0 \pm 0.014$ & $830.0 \pm 0.065$ & $412.0 \pm 0.015$ & $422.0 \pm 0.022$ & BDL & $6338 \pm 0.166$ & 176.0 \\
\hline 6 & & $136.0 \pm 0.005$ & $346.0 \pm 0.003$ & $900.0 \pm 0.006$ & $478.0 \pm 0.014$ & $743.0 \pm 0.020$ & $176.0 \pm 0.022$ & $4504 \pm 0.114$ & $294.0 \pm 0.102$ \\
\hline 7 & & $106.0 \pm 0.005$ & $280.0 \pm 0.003$ & $1190 \pm 0.019$ & $912.0 \pm 0.006$ & $865.0 \pm 0.023$ & $266.0 \pm 0.022$ & $1238 \pm 0.089$ & $208.0 \pm 0.090$ \\
\hline 8 & \multirow[t]{2}{*}{ B } & $106.0 \pm 0.002$ & $236.0 \pm 0.010$ & $1018 \pm 0.009$ & $800.0 \pm 0.002$ & $769.0 \pm 0.002$ & $\mathrm{BDL}$ & $1290 \pm 0.297$ & $\mathrm{BDL}$ \\
\hline 9 & & $88.00 \pm 0.009$ & $274.0 \pm 0.009$ & $1176 \pm 0.004$ & $898.0 \pm 0.005$ & $1095.0 \pm 0.022$ & $\mathrm{BDL}$ & $798.0 \pm 0.121$ & $204.0 \pm 0.147$ \\
\hline 10 & \multirow{14}{*}{$\mathrm{C}$} & $88.00 \pm 0.003$ & $162.0 \pm 0.005$ & $562.0 \pm 0.013$ & $376.0 \pm 0.013$ & $525.0 \pm 0.025$ & $56.00 \pm 0.033$ & $1196 \pm 0.029$ & $\mathrm{BDL}$ \\
\hline 11 & & $130.00 \pm 0.004$ & $332.0 \pm 0.011$ & $876.0 \pm 0.009$ & $552.0 \pm 0.015$ & $505.0 \pm 0.023$ & $134.0 \pm 0.029$ & $4800 \pm 0.061$ & $162.0 \pm 0.081$ \\
\hline 12 & & $94.00 \pm 0.002$ & $144.0 \pm 0.005$ & $510.0 \pm 0.022$ & $370.0 \pm 0.031$ & $577.0 \pm 0.022$ & $62.00 \pm 0.031$ & $1274 \pm 0.078$ & $\mathrm{BDL}$ \\
\hline 13 & & $96.00 \pm 0.013$ & $378.0 \pm 0.016$ & $820.0 \pm 0.015$ & $446.0 \pm 0.003$ & $812.0 \pm 0.022$ & $290.0 \pm 0.089$ & $5718 \pm 0.091$ & BDL \\
\hline 14 & & $94.00 \pm 0.008$ & $242.0 \pm 0.014$ & $742.0 \pm 0.039$ & $474.0 \pm 0.027$ & $709.0 \pm 0.012$ & $76.00 \pm 0.011$ & $2992 \pm 0.149$ & $\mathrm{BDL}$ \\
\hline 15 & & $86.00 \pm 0.003$ & $170.0 \pm 0.002$ & $594.0 \pm 0.025$ & $412.0 \pm 0.018$ & $531.0 \pm 0.002$ & $258.0 \pm 0.109$ & $1972 \pm 0.223$ & $\mathrm{BDL}$ \\
\hline 16 & & $72.00 \pm 0.024$ & $168.0 \pm 0.015$ & $478.0 \pm 0.113$ & $316.0 \pm 0.015$ & $1503.0 \pm 0.022$ & $292.0 \pm 0.037$ & $1586 \pm 0.085$ & $\mathrm{BDL}$ \\
\hline 17 & & $62.00 \pm 0.014$ & $104.0 \pm 0.003$ & $502.0 \pm 0.010$ & $218.0 \pm 0.002$ & $679.0 \pm 0.029$ & $192.0 \pm 0.074$ & $578.0 \pm 0.016$ & $\mathrm{BDL}$ \\
\hline 18 & & $58.00 \pm 0.006$ & $178.0 \pm 0.008$ & $582.0 \pm 0.018$ & $296.0 \pm 0.006$ & $607 \pm 0.022$ & $\mathrm{BDL}$ & $1694 \pm 0.033$ & $\mathrm{BDL}$ \\
\hline 19 & & $70.00 \pm 0.003$ & $164.0 \pm 0.001$ & $806.0 \pm 0.029$ & $396.0 \pm 0.007$ & $538.0 \pm 0.022$ & $202.0 \pm 0.047$ & $564.0 \pm 0.088$ & $\mathrm{BDL}$ \\
\hline 20 & & $32.00 \pm 0.001$ & $220.0 \pm 0.003$ & $678.0 \pm 0.010$ & $378.0 \pm 0.003$ & $565.0 \pm 0.009$ & $\mathrm{BDL}$ & $4506 \pm 0.116$ & $\mathrm{BDL}$ \\
\hline 21 & & $30.00 \pm 0.004$ & $200.0 \pm 0.006$ & $458.0 \pm 0.004$ & $270.0 \pm 0.009$ & $813.0 \pm 0.022$ & $\mathrm{BDL}$ & $3998 \pm 0.031$ & $\mathrm{BDL}$ \\
\hline 22 & & $30.00 \pm 0.003$ & $244.0 \pm 0.007$ & $936.0 \pm 0.045$ & $490.0 \pm 0.015$ & $444.0 \pm 0.012$ & $384.0 \pm 0.118$ & $752.0 \pm 0.013$ & BDL \\
\hline 23 & & $36.00 \pm 0.001$ & $234.0 \pm 0.002$ & $976.0 \pm 0.012$ & $534.0 \pm 0.002$ & $636.0 \pm 0.002$ & BDL & $1126 \pm 0.198$ & BDL \\
\hline
\end{tabular}

$* \mathrm{BDL}=$ Below detection limit

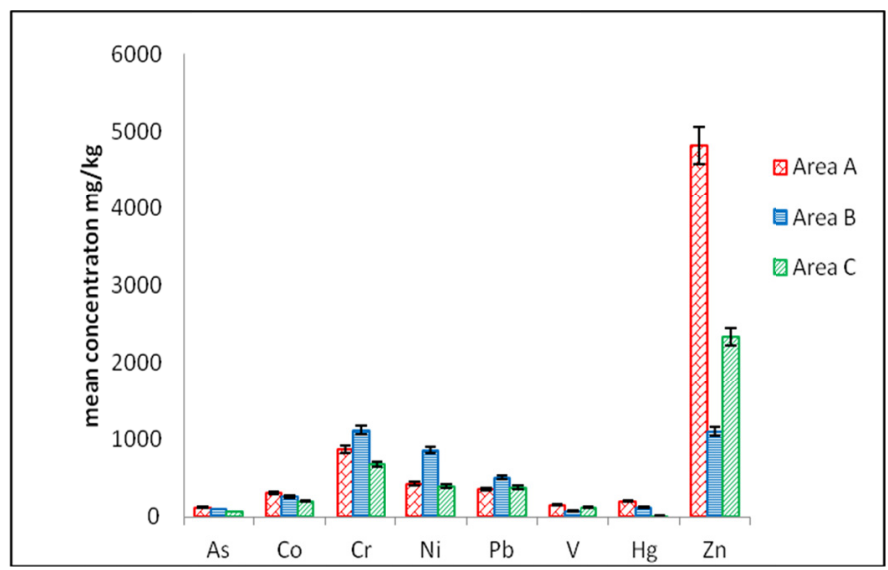

Figure 2. Average concentrations of heavy metal ions in soil at areas (A, B and C) by acid digestion.

Table 3. Average concentrations of toxic metal in area $\mathrm{A}, \mathrm{B}$, and $\mathrm{C}$ using aqua regia digestion in $\mathrm{mg} / \mathrm{kg}$ and tolerable level of soil

\begin{tabular}{ccccc}
\hline Element & Area (A) & Area (B) & Area (C) & Tolerable level (mg/kg) (Lee et. Al., 2009). \\
\hline $\mathrm{As}$ & $122.6 \pm 0.2$ & $100.0 \pm 0.5$ & $69.40 \pm 0.4$ & 6.0 \\
$\mathrm{Co}$ & $310.0 \pm 0.8$ & $263.4 \pm 1.4$ & $210.0 \pm 0.9$ & 100 \\
$\mathrm{Cr}$ & $872.0 \pm 2.5$ & $1128 \pm 5.4$ & $680.0 \pm 3.4$ & 4.0 \\
$\mathrm{Ni}$ & $434.6 \pm 3.1$ & $870.0 \pm 2.5$ & $394.8 \pm 1.8$ & 40 \\
$\mathrm{~Pb}$ & $700.5 \pm 149$ & $792.33 \pm 167$ & $674.6 \pm 184$ & 100 \\
$\mathrm{~V}$ & $152.6 \pm 2.5$ & $75.40 \pm 3.1$ & $124.8 \pm 1.4$ & 4.0 \\
$\mathrm{Hg}$ & $208.0 \pm 2.6$ & $120.0 \pm 2.1$ & $11.60 \pm 1.0$ & 4.0 \\
$\mathrm{Zn}$ & $4821 \pm 10.2$ & $1108.6 \pm 9.5$ & $2339 \pm 8.7$ & 300 \\
\hline
\end{tabular}

\subsection{Environmental Quality Guidelines}

The use of environmental quality guidelines assists the evaluation of other metal-contaminated sites. The tolerable level of soil describes in Table 3 (Lee et. al., 2009). Table 3 shows that the arsenic, mercury, chromium, cobalt, lead, 
vanadium, nickel and zinc were found to be above the tolerable level in comparisons with the other results. This is indicated that almost toxic metals in the three areas were exceeding the tolerable level. Thus, confidently state that the study areas were contaminated with most toxic metals that might pose a potential environmental risk. These results are in good agreement with the observation of Hakami and El-Sayed, 2014. In fact, water represents an important pathway for the dispersion of metals over large areas; while soils are significant basins for metals (FOrstner and Wittmann, 1981). The microorganism can be affected when metals are introduced to its life process.

Groundwater and surface water pollution occurs by dissolution in rainwater (or any other liquid solvent that may be present) and transport through the soil by gravitational, diffusional, and capillary forces. Various metals, such as $\mathrm{Ca}$, Co, $\mathrm{Cr}, \mathrm{Cu}, \mathrm{Fe}, \mathrm{K}, \mathrm{Mn}, \mathrm{Mg}, \mathrm{Na}, \mathrm{Ni}$, and $\mathrm{Zn}$, are essential. Required as micronutrients and for the redox processes to stabilize molecules through electrostatic interactions (components of several enzymes) for regulation of osmotic pressure (Gerber, 1991). Toxicity of nonessential metals occurs when the displacement of essential metals from their binding sites or through ligand interactions. It is well known that the $\mathrm{Hg}^{2+}, \mathrm{Cd}^{2+}$ and $\mathrm{Ag}^{+}$tend to bound with $\mathrm{SH}$ groups of biomolecules (proteins and/or enzymes). Thus, inhibit the activity of sensitive enzymes and produces a smell of hydrogen sulfide.

Table 4. Latin Square Design (LSD) for multiple comparisons of significance areas

\begin{tabular}{|c|c|c|c|c|c|c|c|}
\hline \multirow{4}{*}{ Element } & \multirow{4}{*}{ Area } & \multirow{4}{*}{ Areas } & \multirow{4}{*}{$\begin{array}{c}\text { Mean } \\
\text { difference }\end{array}$} & \multirow{4}{*}{ Std. Error } & \multirow{4}{*}{ Sig. } & 95 & Confidence \\
\hline & & & & & & \multicolumn{2}{|c|}{ Interval for mean } \\
\hline & & & & & & Lower & Upper \\
\hline & & & & & & Bound & Bound \\
\hline \multirow{6}{*}{ As } & \multirow[t]{2}{*}{$\mathrm{A}$} & $\mathrm{B}$ & 22.667 & 18.424 & 0.233 & -15.76 & 61.10 \\
\hline & & $\mathrm{C}$ & $52.810 *$ & 12.713 & 0.000 & 26.29 & 79.33 \\
\hline & \multirow[t]{2}{*}{$\mathrm{B}$} & $\mathrm{A}$ & -22.667 & 18.424 & 0.233 & -61.10 & 15.76 \\
\hline & & $\mathrm{C}$ & 30.143 & 16.576 & 0.083 & -4.430 & 64.72 \\
\hline & \multirow[t]{2}{*}{$\mathrm{C}$} & A & $-52.810^{*}$ & 12.713 & 0.000 & -79.33 & -26.29 \\
\hline & & B & -30.143 & 16.576 & 0.084 & -64.72 & 4.43 \\
\hline \multirow{6}{*}{ Co } & \multirow[t]{2}{*}{ A } & $\mathrm{B}$ & 46.667 & 43.830 & 0.300 & -44.76 & 138.09 \\
\hline & & $\mathrm{C}$ & $100.00^{*}$ & 30.246 & 0.004 & 36.91 & 163.09 \\
\hline & \multirow[t]{2}{*}{ B } & $\mathrm{A}$ & -46.667 & 43.830 & 0.300 & -138.09 & 44.76 \\
\hline & & $\mathrm{C}$ & 53.333 & 39.435 & 0.191 & -28.930 & 135.59 \\
\hline & \multirow[t]{2}{*}{$\mathrm{C}$} & A & $-100.00 *$ & 30.246 & 0.004 & -163.09 & -36.91 \\
\hline & & $\mathrm{B}$ & -53.333 & 39.435 & 0.191 & -135.59 & 28.93 \\
\hline \multirow{6}{*}{$\mathrm{Cr}$} & \multirow[t]{2}{*}{ A } & $\mathrm{B}$ & $-256.00 *$ & 110.381 & 0.031 & -486.25 & -25.750 \\
\hline & & $\mathrm{C}$ & $192.000 *$ & 76.1700 & 0.020 & 33.110 & 350.89 \\
\hline & \multirow[t]{2}{*}{ B } & A & $256.00^{*}$ & 110.381 & 0.031 & 25.750 & 486.25 \\
\hline & & $\mathrm{C}$ & $448.00 *$ & 99.314 & 0.000 & 240.83 & 655.17 \\
\hline & \multirow[t]{2}{*}{$\mathrm{C}$} & A & $-192.00 *$ & 76.170 & 0.020 & -350.89 & -33.11 \\
\hline & & $\mathrm{B}$ & $-448.00 *$ & 99.314 & 0.000 & -655.17 & -240.83 \\
\hline \multirow{6}{*}{$\mathbf{N i}$} & \multirow[t]{2}{*}{ A } & $\mathrm{B}$ & $-435.33^{*}$ & 62.773 & 0.000 & -566.28 & -304.39 \\
\hline & & $\mathrm{C}$ & 39.810 & 43.318 & 0.369 & -50.55 & 130.17 \\
\hline & \multirow[t]{2}{*}{ B } & A & $435.333^{*}$ & 62.773 & 0.000 & 304.39 & 566.28 \\
\hline & & $\mathrm{C}$ & $475.143^{*}$ & 56.479 & 0.000 & 357.33 & 592.96 \\
\hline & \multirow[t]{2}{*}{$\mathrm{C}$} & A & -39.810 & 43.318 & 0.369 & -130.17 & 50.550 \\
\hline & & $\mathrm{B}$ & $-475.143^{*}$ & 56.479 & 0.000 & -592.96 & -357.33 \\
\hline \multirow{6}{*}{ Zn } & \multirow[t]{2}{*}{ A } & $\mathrm{B}$ & $3379.33^{*}$ & 1446.691 & 0.030 & 361.59 & 6397.08 \\
\hline & & $\mathrm{C}$ & $2148.286^{*}$ & 998.312 & 0.044 & 65.840 & 4230.73 \\
\hline & \multirow[t]{2}{*}{ B } & A & $-3379.333^{*}$ & 1446.691 & 0.030 & -6397.08 & -361.59 \\
\hline & & $\mathrm{C}$ & -1231.048 & 1301.639 & 0.356 & -3946.22 & 1484.12 \\
\hline & \multirow[t]{2}{*}{$\mathrm{C}$} & A & $-2148.286^{*}$ & 998.3120 & 0.044 & -4230.73 & -65.84 \\
\hline & & B & 1231.048 & 1301.639 & 0.356 & -1484.12 & 3946.22 \\
\hline
\end{tabular}

* The mean difference is significant at $95 \%$ confidence.

\subsection{Statistical Analysis}

The better describe to test the comparable alternative of the high level of toxic elements and the correlation factor between the three sample areas. Thus, database was analyzed statistically by Latin square design (LSD) using SPSS software. The data in Table 4 revealed that a strong association for high values of toxic metals As, $\mathrm{Cr}, \mathrm{Ni}, \mathrm{Zn}$ and $\mathrm{Co}$ at area $\mathrm{A}$ to the surrounding area $\mathrm{B}$, and $\mathrm{C}$. These data also reflect a significant correlation between area $\mathrm{B}$ and area $\mathrm{C}$ of the tested toxic metal ions. Sewage Lake area (A) which is major contaminated by the toxic metals that had a significant contribution in the neighborhood areas (B) and (C). Other study in the same area was performed to investigate the remediation of the same site of soil samples using $\mathrm{HCl}(0.1 \mathrm{M})$. The results showed excellent correlation between the levels of $\mathrm{Co}$, As, and $\mathrm{Hg}$ with the distance from the central polluted area (Alghanmi et. Al., 2015). Suggest, more study need to take for monitoring the environmental geochemistry of the sewage lake area and sufficient remediation such as bioremediation (Cecchi et. al., 2017) and phytoremediation (Bolan et. Al., 2014). 


\section{Conclusions}

The research data illustrate the influence of anthropogenic agents on the abundance of toxic metals in 23 soil samples from three areas near Sewage Lake in Jeddah. The study revealed a high accumulation of toxic metals (As, $\mathrm{Co}, \mathrm{Cr}, \mathrm{Hg}$, $\mathrm{Ni}, \mathrm{V}, \mathrm{Pb}$, and $\mathrm{Zn}$ ) in the soil stimulates an increase in their level due to the random dumping of hazardous waste associated with the sewage effluents from houses, hospitals, and industries that might be causing a leaching it into the ground waters. The average concentration of $\mathrm{Zn}(4821 \pm 10.2 \mathrm{mg} / \mathrm{kg})$ at area A was much higher than the other two areas and exceeded the permissible level of $\mathrm{Zn} 300 \mathrm{mg} / \mathrm{kg}$. For Cr the average concentration was $1128 \pm 5.4 \mathrm{mg} / \mathrm{kg}$ at areas B was higher than the area $\mathrm{A}$ and $\mathrm{C}$ and exceeded the tolerance level $4.0 \mathrm{mg} / \mathrm{kg}$. In area $\mathrm{B}$, the concentration of $\mathrm{Ni}$ $(870.0 \pm 2.5 \mathrm{mg} / \mathrm{kg})$ and $\mathrm{Pb}(792.33 \pm 167 \mathrm{mg} / \mathrm{kg})$ was also comparatively higher and above the permissible limit. The concentration of As and $\mathrm{Hg}$ was present minimum in area $\mathrm{C}$ but maximum in area A. Overall, the high level of toxic metals in soil samples were moderately or heavily contaminated at the three areas. Thus, indicated that the soil of the studied areas, mainly polluted from the uncontrolled discharge of effluents to the waterborne Sewage Lake. The correlation factor between the study areas shows a significant contribution of toxic metals concentration according to the contamination of area A Sewage Lake region with other study areas (B and C). The study points out the soil quality measurements are required in all the three areas and adequate potential treatment should execute, such as bioremediation, phytoremediation by implanting certain plants in the area that could reduce the rate of contamination and avoid the polluted problems in the future.

\section{Acknowledgment}

The authors would like to thank King Abdulaziz University for support and facilities this project.

\section{References}

Adham, K. G., Al- Eisa, N. A., \& Farhood, M. H. (2011). Risk assessment of heavy metal contamination in soil and wild Libyan jird Meriones libycus in Riyadh, Saudi Arabia. Journal of Environmental Biology, 32, 813-819.

Alghanmi, S. I., AlSulami, A. F., El-Zayat, T. A., Alhogbi, B. G., \& Abdel, S. M. S. (2015). Acid Leaching of heavy metals from contaminated soil collected from Jeddah, Saudi Arabia: kinetic and thermodynamics studies. International Soil and Water Conservation Research, 3, 196-208. https://doi.org/10.1016/j.iswcr.2015.08.002

Alloway, B. J., \& Ayres, D. C. (1997). Chemical Principles of Environmental Pollution, 2nd Edition, Blackie Academic \& Professional, New York, LONDON.

Bolan, N., Kunhikrishnan, A., Thangarajan, R., Kumpiene, J., Park, J., Makino, T., ... Scheckel, K. (2014). Remediation of Heavy Metal (loid)s Contaminated Soils-to Mobilize or to Immobilize? Journal of Hazardous Materials, 266(15):141-166. https://doi.org/10.1016/j.jhazmat.2013.12.018

Cecchi, G., Roccotiello, E., Di Piazza, S., Riggi, A., Mariotti, G. M., \& Zotti, M. (2017). Assessment of Ni accumulation capability by fungi for a possible approach to remove metals from soils and waters. Journal of Environmental Science and Health, Part B, Pasticides, Food Contaminants, and Agricultural Wastes, 52(3), 166-170. https://doi.org/10.1080/03601234.2017.1261539

CIA, Central Intelligence Agency, The World Fact Book, (2008) Saudi Arabia. http://www.cia.gov/library/publication/the-world- Facebook/geos/Sa.html, Accessed: 26 April (2012).

Cos, M., Kun, E., Steinnes, M. V., Frontasyeva, T. E., \& Sjobakk, S. D. (2006). Heavy metal pollution of surface soil in the Thrace Region, Turkey, Environ. Monit. Assess., 119, 545-556. https://doi.org/10.1007/s10661-005-9042-3

Douay, F. H., Roussel, H., Fourrier, C., \& Heyman, G. C. (2007). Investigation of heavy metal concentrations on urban soils, dust and vegetables nearby a former smelter site in Mortagne du Nord, Northern France, J. Soils Sediments 7:143-146. https://doi.org/10.1065/jss2007.02.205

Dumping Site in Nairobi, Kenya, Report Summary, http://2www.unep.org/urban environment U2T. Accessed: 23.9. (2011).

EcoMENA, Echoing Sustainability, Middle East Solid Waste Management Issue, April (2016) http://www.ecomena.org/swm-ksa-ar/

FÖrstner, U., \& Wittmann, G. T. W. (1981). Metal Pollution in Aquatic Environment, 2nd Edition, Springer-Verlage, Berlin, Heidelberg, New York, 486.

Gäbler, H. (1997). Mobility of heavy metals as a function of $\mathrm{pH}$ of samples from an overbank sediment profile contaminated by mining activities, Journal of Geochemical Exploration, 58, 185-194. https://doi.org/10.1016/S0375-6742(96)00061-1

Gerber, H. (1991). Probability distribution of aerosol backscatter in the lower marine atmosphere at $\mathrm{CO}_{2}$ wavelengths, $J$. 
Geophys. Res., 96, 5307-5314. https://doi.org/10.1029/89JD00693

Habibullah, A. M. (2014). Sustainable Strategies for Urban Water Management for Arid Region: The Case Study of Jeddah City Saudi Arabia. By THESIS of Msc. The University of Illinois at Urbana-Champaign, Urbana, Illinois, USA.

Hakami, B. A., \& El-Sayed, S. A. (2014). Geo-Environmental Assessment of Hazardous Effects of Disposal Wastewater, Jeddah, Red Sea Coast, Saudi Arabia, International Journal of Innovative Research \& Development, 3(4), 170-179.

Jeddah municipality, Jeddah news http://www.arabnews.com/saudi-arabia/news/20 $0^{\text {th }}$ February (2010).

Kelepertzis, E. (2014). Accumulation of Heavy Metals in Agricultural Soils of Mediterranean: Insights from Argolida basin, Peloponnese, Greece. Geoderma, 221, 82-90. https://doi.org/10.1016/j.geoderma.2014.01.007

Lee, C. S. L., Li, X. D., Shi, W. Z., Cheung, S. C. N., \& Thornton, I. (2006). Metal contamination in urban, suburban, and country park soils of Hong Kong: A study based on GIS and multivariate statistics, Sci. Total Environ. 356, 45-61. https://doi.org/10.1016/j.scitotenv.2005.03.024

Lee, H., Kabir, I. Md., Kown, S. P., Kim, M. J., Kim, G. J., Huyn, H. S., ... Jung, S. M. (2009). Contamination Assessment of Abandoned Mines by Integrated Pollution Index in the Han River Watershed, The open Environmental Pollution and Toxicology Journal, 1, 27-33.

Li, Z., Ma, Z., van der Kuijp, T. J., Yuan, Z., \& Huang, L. (2014). A review of soil heavy metal pollution from mines in China: Pollution and health risk assessment. Sci Total Environ., 843-853. https://doi.org/10.1016/j.scitotenv.2013.08.090

Lim, H., Lee, J., Chon, H., \& Sager, M. (2008). Heavy Metal Contamination and Health Risk Assessment in the Vicinity of the Abandoned Songcheon Au-Ag Mine in Korea. Journal of Geochemical Exploration, 96, 223-230. https://doi.org/10.1016/j.gexplo.2007.04.008

Magram, S. F. (2009). A Review on the Environmental Issues in Jeddah, Saudia Arabia with Special Focus on Water Pollution. Journal of Environmental Science and Technology, 2(3), 120-132. https://doi.org/10.3923/jest.2009.120.132

Odewande, A. A., \& Abimbola, A. F. (2008). Contamination indices and heavy metal concentrations in urban soil of Ibadan metropolis, southwestern Nigeria, Environ. Geochem. Health, 30, 243-254. https://doi.org/10.1007/s10653-007-9112-2

Romic, M., \& Romic, D. (2003). Heavy metals distribution in agricultural top soils in urban area, Environmental Geology. 43(7), 795-805.

Ron, E. Z., Minz, D., Finkelstein, N. P., \& Rosenberg, E. (1992). Interactions of Bacteria with Cadmium, Biodegradation, 3, 161-170. https://doi.org/10.1007/BF00129081

Sow, A. Y., Ismail, A., \& Zulkifli, S. Z. (2013). Geofractionation of heavy metals and application of indices for pollution prediction in paddy field soil of Tumpat, Malaysia. Environ Sci Pollut Res Int. 20, 8964-8973. https://doi.org/10.1007/s11356-013-1857-9

Sun, Y., Zhou, Q., Xie, X., \& Liu, R. (2010). Spatial, sources and risk assessment of heavy metal contamination of urban soils in typical regions of Shenyang, China. Journal of Hazardous Materials, 174, 455-462. https://doi.org/10.1016/j.jhazmat.2009.09.074

UNEP, United Nations Environment Program, Implications of the Dandora Municipal

Ure, A. M. (1995). Heavy Metal in Soil, Method of analysis for heavy metals in soil, In Alloway B. J. 2nd. Blackie Academic and Professional, New York, LONDON, 58-94.

Wang, L, K., Pereira, C. N., \& Hung, Y. (2004). Advanced air and noise pollution control. Volume 2, Humana Press, Totowa, New Jersey, 127. https://doi.org/10.1007/978-1-59259-778-9

Zhao, H., Xia, B., Fan, C., Zhao, P., \& Shen, S. (2012). Human health risk from soil heavy metal contamination under different land uses near Dabaoshan Mine, Southern China. Sci Total Environ, 45-54. https://doi.org/10.1016/j.scitotenv.2011.12.047

\section{Copyrights}

Copyright for this article is retained by the author(s), with first publication rights granted to the journal.

This is an open-access article distributed under the terms and conditions of the Creative Commons Attribution license (http://creativecommons.org/licenses/by/4.0/). 